\title{
RELIGIOUS IDENTITY OF BULGARIAN CATHOLICS' COMMUNITIES
}

\author{
Rasa Račiūnaitè-Paužuolienè \\ Department of Cultural Studies, Vytautas Magnus University, Kaunas, Lithuania \\ e-mail:r.raciunaite@hmf.vdu.lt
}

\begin{abstract}
This article analyses the issue of religious identity of Bulgarian Catholics during the start of the 2000s. The paper is based on ethnographic fieldwork materials gathered by the author in Bulgaria in 2015-2017. It presents the results of a research, carried out on a comparative basis among the communities of Bulgarian Catholics from Sofia, Plovdiv and its regions (in the villages of General Nikolaevo, Sekirovo (today forming the quarters of the town of Rakovski), Kaloyanovo, Belozem, Zhitnitsa).

The research performed by this author reveals that religious identity of Bulgarian Catholics is not a unified one. There are some different characteristics and peculiarities among the local and regional religious identity of this confessional community. The presented observations confirm the thesis that the local and regional religious identity of Roman Catholics are interconnected and mutually dependent. Further, the cultural and religious forms of Bulgarian Catholics' religiosity are transformed through acculturation and they are put in a new context with a distinctive cultural and religious identity.
\end{abstract}

Keywords: Bulgaria, Bulgarian Catholics' communities, religious identity 


\section{Introduction}

Today religious identity among Bulgarians coincides with the differences in their faiths, which, in Bulgaria, are Eastern-Orthodox, Muslim, Protestant, Roman Catholic, Uniat and other Christian confessions ${ }^{1}$. The study presents the religiosity of Bulgarian Catholics for the period between the second part of the $20^{\text {th }}$ century and the second decade of the $21^{\text {st }}$ century. This chronological framework marks the time of transition from tradition to modernity among the communities of Bulgarian Catholics. The study focuses on the so-called southern pavlikjans, but it does not include the so-called northern pavlikjans, Banat Bulgarians, as well as Uniates who formally adopted Catholicism during the struggle for church independence during the Bulgarian National Revival period (Jankov 2003: 326).

The aim of this paper is to analyse the religious identity, as well as traditions and innovations of religious forms of contemporary Bulgarian Catholics. Moreover, the study specially focuses on the local and regional religious identity of the communities of Bulgarian Catholics. Religion as one of the most significant features of identity helps individual to determine the purpose of human life, and serves as a source of moral support. Moreover, "religious activity helps make individual aware of their community, enables them to symbolically express the social order, gain an objective awareness of society" (Serafimova 2011: 116).

The aim is to answer the following questions: How do different generations of Bulgarian Catholics understand the Roman Catholic identity nowadays? How does the religious identity become pronounced in contemporary Bulgarian Catholics life? This article deliberates the problem of changes in religious identity in Bulgaria during the start of the 2000s.

Methodology. This paper presents the results of a research, carried out on a comparative basis among the communities of Bulgarian Catholics from Sofia, Plovdiv, as well as in the villages of General Nikolaevo, Sekirovo (today forming the quarters of the town of Rakovski), Belozem, Kaloyanovo, Zhitnitsa in the region of Plovdiv from the $24^{\text {th }}$ March to the $5^{\text {th }}$ April 2017, and from the $1^{\text {st }}$ to the $14^{\text {th }}$ October 2010 .

The ethnographic material was gathered by the author using anthropological fieldwork methods such as the questionnaire form, discussions, structured and semi-structured interviews, observation methods. 38 respondents from 
different social strata were interviewed (students, pensioners, teachers, scholars, businessmen, white/blue-collar workers, priests (Catholics, Orthodox, Uniates, nuns, and monks)). The stratification of the sample was accomplished by gender, age and social strata. The sample contained 38 respondents, 17 of whom were female and 21 male. The age of respondents ranged from 26 to 80 .

In recent years the Bulgarian Catholics have received rather great attention from different scholars. There are some surveys related to historical sociocultural, political, and religious aspects of Bulgarian Catholics (Curtis 1992; Brown 1983; Kanev 2002; Kent 2002; Leustean 2014; Eade 2012), local varieties of family and calendar feasts of Bulgarian Catolics (Boncheva 2005; Jankov 2003), local treatment of religion as a marital ban in view of its role as a key marker in constituting the community identity (Boncheva 2006), the distinctiveness of musical culture and national identity among the Bulgarian Catholics (Grozdew 2004), the interrelationship of Christians and Muslims in Bulgaria (Georgieva 1999).

\section{Catholicism in Bulgaria}

Catholicism in Bulgaria is the result of a complex and heterogeneous historicalpolitical process (Grozdew 2014: 257). According to Janice Brown, although Bulgaria's Catholics now form one of the smallest Catholic national communities, numbering about seventy thousand, Bulgaria might have been a Catholic nation. Tsar Boris, baptised in $864 \mathrm{AD}$, approached both the Patriarch of Constantinople and the Pope, and at first leant towards Rome, but finally chose Orthodoxy in 870 (Brown 1983: 310). Catholicism in Bulgaria is related to missionary activities of the Passionists, the Capuchins, the Franciscans, and the Benedictine nuns who came from Italy, France (Grozdew 2014) and Poland. Their influence on Bulgaria's Catholics is not denied.

The policy of containment during Soviet times separated Catholic Europeans of the West from Catholics of the East for forty years and resulted in extensive persecution of the Church in Eastern Europe (Kent 2002: 5). In the early 1950s, the property of Bulgarian Catholic parishes was confiscated, all Catholic schools, colleges, and clubs were closed, and the Catholic Church was deprived of its legal status. Only nominal official toleration of Catholic worship remained (Curtis 1992: 90-91). According to Brown, by 1983 church 
life was generally stagnant, the Catholic community was 'paralysed by fear and depressed by ghetto conditions and poverty' (Brown 1983: 314). Despite the Communist regime's attempts to eliminate religion in Bulgaria as part of secularisation strategy, Catholicism only weakened rather than faded away completely.

With the collapse of the Soviet Union and democratic transformations in East Europe, the Roman Catholic Church in Bulgaria became a common part of the European Catholic Church. According to Peter Kent, 'the Roman Catholic Church had been one of the defining institutions of the concept of Europe and, through the development of Western Christendom, of European culture and civilization' (Kent 2002: 21). West European countries, such as Italy, Austria, Germany, France, Croatia, Poland, made a big impact on Catholic Church tradition in Bulgaria. Croatia's community has very old Catholic traditions in Sofia, whose representatives from Dubrovnik, as merchants arrived in Bulgaria in the Middle Ages. Italian cultural and religious influence on Bulgaria's Catholics is also very vivid. Nowadays Vatican is the most important centre for the study of Bulgarian Catholic priests. Austria's cultural and religious impact on Bulgarian culture is not denied. Sofia city was constructed according to the Vienna city' model, the support of Austrian Catholics was appreciated, as well.

There are three religious centres (Ruse, Plovdiv and Sofia) of Catholicism in contemporary Bulgaria. The oldest Roman Catholics' diocese of Plovdiv and Sofia was founded in 1601, as well as Ruse (diocese of Nikopol) in 1648. Majority of Bulgarian Catholics' communities are mainly situated around the centres of Ruse, Svischtov and Nikopol, as well as Plovdiv. There are some villages inhabited by the Catholic believers in Plovdiv region: Belozem, Borec, Duvanlii, Kaloyanovo, Miromir (Partchevich, Sekirovo, General Nikolaevo nowadays the town of Rakovski), and Zhitnitsa.

\section{St. Joseph Catholics' Parish in Sofia}

Bulgarian Catholics from Sofia are closed up around Saint Joseph's Cathedral, which is located in the heart of Sofia, across from ruins of ancient Serdica, near the Central Mosque, the Synagogue, and the Central Market Hall. The temple is the co-cathedral of the Diocese of Sofia and Plovdiv, together with the Cathedral of St. Louis in Plovdiv. It has a long and complex history from its 
construction, which started in 1875. Gradually, the parish began to increase due to the fact that foreign Catholics (Croatians, Germans, Austrians, the French) were visiting Bulgarian capital. Unfortunately, the church was destroyed by the Allied bombing raid during World War II (30.03.1944). The cathedral was rebuilt only after 60 years, on 2006 at its previous location after Pope John Paul II's visit to Bulgaria in 2002 (Pelovska 2006; Nikolova 2006).

Nowadays about 700 Catholics (in 2011 there were 3000 parishioners) attend the Holy Mass at St. Joseph Church every week. Sunday service attracts around 100 parishioners, ranging from regular Bulgarians to foreign diplomats speaking different languages. Its multicultural and multilingual character is a peculiar feature which singles the parish out from other Bulgarian parishes. While the church is attended by $80 \%$ of Bulgarians, its members include foreigners (Poles, Croats, Austrians, French, Italians, Romanians, Arabs, Filipinos, Lebanese, Vietnamese), those who come from different backgrounds and make different contributions. E.g., Catholics from Indonesia and Columbia practice local forms of popular devotion: they place bracelets at the foot of Mary's sculpture; Bulgarians place roses there - the national Bulgarian symbol. In the process, new forms of liturgy emerge. Some communities, e.g., French, include elements characteristic of liturgy celebrated in their country. Italian community prefers the midday Latin Mass, with roots back to early in the present century, while the Polish community attends the service, carried out in the Polish language, and incorporating distinctive elements of Polish liturgy.

The parish life is enlivened by organ concerts, nearby is a hostel which houses a considerable number of Catholic students, the course of catechumenate, which lasts for two or three years, enjoys great popularity among adult parishioners. Additionally, the parish organises pilgrimages to various sacred places of Bulgaria. During the Holy Week in April 2017, the author made a participant observation at the Road of the Cross organised by the parish members on the hill of Vitosha. The ceremony was led by three Polish Capuchins from the St. Joseph parish, accompanied by parish community members from seven European countries. Catholics in Bulgaria have a longstanding tradition to celebrate Marian feast in May in the mountains - there they celebrate the Holy Mass, pray rosary, sing chants and litanies venerating God's Mother.

During the fieldwork, the author interviewed the respondents from different ethnic groups (Bulgarians, Poles, Croats, Romanians, Italians, Russians) 
which constituted a common part of St. Joseph Catholics' Church community. Polish Capuchin emphasised the strong faith of Bulgarian Catholics: "Every day they attend the Holy Mess and obey the moral rules and ancient traditions. With the help of grandmothers and grandfathers Bulgarian Catholics saved their faith" (II/3).

One Bulgarian woman who grew up in St. Joseph parish during Soviet times talked about her childhood. When in 1958 her parents had their wedding ceremony at the Catholic Church of St. Joseph, there was only one priest who wasn't imprisoned then. Others were in the concentration camp, under house arrest or simply detained. She mentioned that the Soviets established a tradition to close a church after the parish priest died. The respondent pointed out that "Sad as it was, there were no Catholic priests left in Soviet times. Obviously, it was done on purpose. Clearly, it was a form of repression..." (II/1).

Annihilating the clergy, the Soviets strived to undermine the pastoral activity within the Catholic Church, to instil fear and distrust among parishioners, also, to weaken the Catholic religious identity. According to respondent,

Repressions targeted not only the Catholic Church, but also the Bulgarian Orthodox and Unitarian Churches. The latter have kept unity with the Catholic Church until now - repressions both Churches underwent during Soviet times and other negative experience they had then brought them even closer (II/1).

The Catholic and Unitarian Churches have maintained strong spiritual bonds until now, Unitarian priests sometimes even celebrate Mass together with Catholics. Additionally, Unitarian Church members take part in religious events organised by the Catholics, including the adoration of the Holy Sacrament. The author had a chance to talk to a young woman, a parishioner of a Unitarian Church, who every morning on her way to work attends Mass at a Catholic Church and explains it as her inner need.

Young Croatian man, a regular visitor of St. Joseph parish, talked about his religious experience in this parish:

I was baptised about twelve years in 1987. At that time priest was afraid to baptise me. The priest, who baptised me, was one of a few, which were survived at the prison after the War. The priest, called Pavel France. He baptised me secretly in secret ceremony in 1987 with my grandmother and 
her sister in Sofia. At that time it was not so easy. Most only old people was going in the church. The church never stopped the church life, but it was not easy according political situation.

I started as ministrant from twelve to twenty years in the St. Joseph Church. Now I am coming to Latin Mass in Sofia on Sundays. This Latin Mass has very very old tradition in Sofia. The people, who like the Latin Mass, they come on Sunday. A lot of foreign people come in Latin Mass. It's only one place in Sofia [where you can attend the Latin Mass]. Our family like the Latin tradition. During the communist time existed this Latin Mess in Sofia. It's a long tradition in Sofia.

I go to the church every Sunday because I like to go. I need to practice, I feel good, when I come. I feel nice in a church. I like, I am not thinking, that it's duty. I go, because I like to be a part of liturgy. Especially for our small church, I think, it is necessary. Because if people stop do it, would be difficult to survive the church surrounding of Orthodox. So, for me this is an issue. I married an Orthodox girl and we married in Catholic Church, in Cathedral of Plovdiv. Also this is tradition (II/4).

Some religious practices and traditions, mentioned in this interview, are very important for such young man, who has accepted them from his childhood. Such religious traditions are alive and are extended in his and his family life nowadays.

Later he spoke about differences of Bulgarian religiosity between Soviet period and nowadays:

It was difficult years in communist period. The generation between me and my grandparents was much less religious, because it was not easy for them. So, mostly, what I have got, was from my grandparents. Generation of my parents, they are not very religious, because it was not easy to be religious. About 20\% of Orthodox are religious of my generations. Latin Catholics, who feel himself as a part of a community, are religious about 60\%, may be, Uniates about $70 \%$. Uniates are very strong community what I see in Bulgaria. The Orthodox tradition it's not so strong of my generation (II/4).

Another parishioner, born in Sofia in 1959, asked about Bulgarian religious identity, said that "First of all, we are Bulgarians, then Christians, and only after that we break up into Orthodox and Catholics" (II/1). In the case of her 
family, both confessions are equally important, because her father is Orthodox and mother is Catholic. Thus, ethnic identity is considered to be of utmost importance, the second in line is Christian identity and confessional identity comes last.

A scarce number of Bulgarian Catholics, according to the respondent, was determined by two reasons.

The first cause is that lots of Catholics emigrated after the changes took place. None of the children, who accompanied me on the day of the First Communion, live in Bulgaria. I have also been away from the country. When communism came, lots of Bulgarian Catholics who had ties with Western Europe either remained there or managed to escape. After Bulgaria was freed from Turkish yoke there were not many Bulgarian Catholics left, because Catholics took part in the risings for freedom. Many of them died, others fled Bulgaria after the risings (II/1).

\section{The Roman Catholic Communities in Plovdiv Region}

Catholic believers from small villages in the region of Plovdiv are the descendants of Pavlicians, which did not adopt Christianity as long as until the $9^{\text {th }}$ century, later, encouraged by Capuchins, they became zealous Catholics.

Rakovski is the largest predominantly Roman Catholic town in the historical region of Thrace, located in the Plovdiv province. Rakovski was founded in 1966 with the merging of three villages - General Nikolaevo, Sekirovo and Parchevich. According to the statistical data, Rakovski had 25520 population in 2017 (Demographic and Social Statistics 2017).

Nowadays the Catholic Church of Sacred Heart in Rakovski has 6000 Catholics: about $80 \%$ of them are seniors, $15 \%$ - middle generation and only $5 \%$ are youth. According to Catholic priest:

The biggest group of Catholics are women. Bulgarian men not participate in a church; they are aloof from the church life. It's our problem. Young people don't have a deep faith. Such tangible, as a power, property, and a success are appreciable. Bulgarian nation believes in superstitions. One part of people has a deep faith, another part - superficial faith (I/9). 
Another priest from Rakovski told about his childhood:

Communism destroyed the faith of people. Human beings could not attend the Churches. The policemen stood at the churches and destroyed their life. Only communists had possibility to study in the universities, only the grandparents and children could attend the churches. The faith was transmitted from grandparents to grandchildren. I was baptised by my grandmother at night, as well as my friend. The grandmother took me from my mother confidentially and baptised me in the church at night. I was baptised in 1985, after one month in the Nativity of God Mother Church near by Danube. In this church was baptised a bishop Evgenij Bossilkov (1900-1952), born in Belene. He was shot in Sofia, but his body was not discovered until nowadays. During communism time the faith was lost (III/14).

A nun living in Sekirovo told me that the majority of people in the area are Catholics:

Some 8000 Catholics live here, however, most of them are not very devout - less than $50 \%$ of believers come to Mass on Sundays. There are three groups of parishioners: the elder generation (aged 60-70); young adults (aged 20-30), who study the Bible; and children, who study the catechism.

Most parishioners come to church to baptise their children, for the wedding ceremony, however, they don't go to church regularly. The faith of those people has no expression in everyday life, there is no connection between their faith and their deeds. Besides, there's an ongoing discrimination of the Roma. There is a great distance between Bulgarians and the Roma. In Sekirovo one can see that Romany exist as a different community. There are about hundred Roma houses in Sekirovo where three-four families live in each of them. The Roma don't go to Mass because of discrimination. If ever they come to church, they remain standing by the door and are watched by everybody. I say, Jesus loves even his enemies. I speak about Roma's discrimination. I observe people's reaction. They say: "You don't know our experience with the Roma. They are uneducated, they are thieves." People don't want to integrate them. 
Jesus is very radical ordering us to love everybody. Bulgarian people don't accept my words. Faith is associated only with ideas or ideology, it doesn't get deeper (I/3).

Belozem is another village in South Bulgaria, located $38 \mathrm{~km}$ from Plovdiv. It has about 5000 inhabitants. There are 700 Catholics in the Roman Catholic parish in Belozem; due to the demographic situation, the number of Catholics is on the decrease. The village is well developed with excellent infrastructure; a railway station, a town hall, a primary school, a kindergarten, a community centre with library, restaurants and gas stations. The majority of the Belazem population is engaged in farming - agriculture, greenhouses and livestock.

Belozem has two churches - Orthodox and Roman Catholic. This village is famous for a Catholic "International Christian Music Festival Belozem", which has been organised every summer since 2000. It's popular not only among Catholics, but also among Orthodox, Protestants and Muslims as well.

Nowadays, two brothers of the Capuchin Order with native Catholics, help people, do charity work, organise catechesis for children, youths, supervise a Bible study groups for adults. Their Kitchen of Saint Anthony gives fifty daily meals to the poor, especially for Roma people.

Zhitnitsa is one of the small villages in Plovdiv region. A small monastery of Franciscan sisters is located there. In the surroundings of Zhitnitsa, some forms of local popular devotion may be detected. Every day in May, Catholics gather at the crossroads, round small chapels with the statuettes of Mary, bring flowers there and sing chants venerating God's Mother. Every May in the village of Belozem the inhabitants have a procession honouring the Blessed Virgin during which they carry Mary's statue and flowers. Different groups of people (children, youth, and senior) take part in the procession. They stop in four places and read extracts from the Gospel dealing with Mary, Mother of God. Celebrating the feast of the Assumption of Mary, a procession is held again during which the participants chant, pray the rosary and recite a litany. Late in the evening, at about 7 p.m., they walk in a candle procession which lasts for one or one and a half hours (I/1).

There is an old tradition of the Franciscan, known as the Third Order of Saint Francis, in Zhitnitsa. There is a big group of women, about 70, who attend The Assumption of Mary Catholic Church every day. Additionally, every Tuesday they have popular devotions rituals of St. Anthony and his relic, and 
once during the month, they have a common meeting. They have a very strong faith, praying rosary every day, and they have adoration every first Friday during the month. Besides that, they are very simple and have an old tradition to pray together rosary outside. It's possible to see a group of women sitting outside, near their house, who are praying rosary together. Generally speaking, there are a lot of praying traditions in Zhitnitsa village. For example, the families with their children are praying rosary before high Mass every Sunday. People like to pray rosary during funeral. They pray for all family and relatives, for their grandparents, parents and their children, they remember their ancestors. They don't finish praying (I/7).

Consequently, the traditional Catholic religiosity forms, such as rosary prayer, singing chants venerating God's Mother, participating in the processions honouring the Blessed Virgin during every May, are more specific to rural area people.

\section{Conclusion}

In conclusion, the religious identity of Bulgarian Catholics is not a unified one. There are some different characteristics and peculiarities among the local and regional religious identity of those Roman Catholic communities. The presented observations and interviews confirm the thesis that the local and regional religious identity of Roman Catholics is interconnected and mutually dependent.

This investigation reveals that ethnic identity among Bulgarians is considered to be of utmost importance, the second in line is Christian identity and confessional (Orthodox, Catholic, Protestant, Uniat) identity comes last.

This investigation reveals that the grandchildren generally identify themselves more strongly with the Catholic religious identity and Christian values of their grandparents than with their parents. Their mastery of necessary Catholic cultural codes gives them other options in their identity management than were available to their parents. Traditional Catholic religiosity forms such as a daily rosary prayer, singing chants venerating God's Mother, participating in the processions honouring the Blessed Virgin during the May month, are more specific to rural area people. Urban Catholics take priority to pilgrimages to sacred places of Virgin Mary, for example pilgrimages to Lurd in France, or Bachkovo monastery in Plovdiv region. 
The cultural and religious forms of Bulgarian Catholics' religiosity are transformed through acculturation and they are put in a new context with distinctive cultural and religious content of identity.

\section{Acknowledgements}

The present research was carried out in 2015-2017 according to the bilateral international project Contemporary Festivity in Bulgaria and Lithuania - from Traditional Culture to Post-Modern Transformations between Bulgarian Academy of Sciences, Institute of Ethnology and Folklore Studies with Ethnographic Museum and Lithuanian Academy of Sciences, Lithuanian Institute of History. This article was originally given as a paper at the International Conference on "Balkan and Baltic States in United Europe: History, Religion, and Culture III", held at the Lithuanian Institute of History, Vilnius, on 9-11 October 2017.

\section{Notes}

1 According to the survey of EURO 2000 and BBSS Gallup and Balkan British Social Surveys, in Bulgaria, $79 \%$ of the population defines itself as Christian, $16 \%$ as Mus$\lim$ and $5 \%$ as atheist. Amongst the Christian population, $86 \%$ define themselves as Orthodox, less than 1\% together Catholics and Protestants, and 13\% as non-aligned Christians (Kanev 2002: 76).

\section{References}

Boncheva, Cvetana 2005. Brak i semeistvo pri Balgarite katolitsi v Plovdivsko prez p'rvata polovina na 20 vek. [Wedding and Family of Bulgarian Catholics from Plovdiv during the First Half of the $20^{\text {th }}$ Century]. Sofija: Mezhdunaroden tsent'r za izuchavane na maltsinstvata i kulturnite vzaimodeistviia.

Boncheva, Cvetana 2006. Religion within the Context of the Marrital Bans among the Bulgarian Catholics from the Region of Plovdiv during the First Half of the $20^{\text {th }}$ Century. Ethnologia Bulgarica, Vol. 3, pp. 113-127.

Broun, Janice 1983. Catholics in Bulgaria. Religion, State and Society, Vol. 11 (3), pp. 310-320. DOI: 10.1080/09637498308431094. 
Curtis, Glenn (ed.) 1992. Bulgaria: A Country Study. Washington: GPO for the Library of Congress.

Eade, John 2012. Pilgrimage, the Assumptionists and Catholic Evangelisation in a Changing Europe: Lourdes and Plovdiv. Cargo, Vol. 10 (1-2), pp. 27-46.

Jankov, Angel 2003. Kalendarni prazdnici i obichai na balgarite katolici (kraja na XIXsredata na XX vek) [Calendar Feasts and Customs of Bulgarian Catholics (the End of $19^{\text {th }} \mathrm{c}$. - the Middle of $20^{\text {th }} \mathrm{c}$.]. Sofija: "Marin Drinov" press.

Georgieva, Cvetana 1999. Coexistence as a System in the Everyday Life of Christians and Muslims in Bulgaria. Ethnologia Balkanica, Vol. 3, pp. 59-84.

Grozdew, Weronika 2004. National Identity and the Distinctivness of Musical Culture among the Bulgarian Catholic Minority. In: Ursula Hemetek; Gerda Lechleitner et al. (eds.) Manifold Identinites: Studies on Music and Minorities. London: Cambridge Scholars Press, pp. 257-261.

Kanev, Petar 2002. Religion in Bulgaria after 1989: Historical and Sociocultural Aspects. South-East Europe Review for Labour and Social Affairs, issue 1, pp. 75-95.

Kent, Peter 2002. The Lonely Cold War of Pope Pius XII: The Roman Catholic Church and the Division of Europe 1943-1950. Montréal; London; Ithaca: McGill-Queen's University Press.

Leustean, Lucian 2014. Eastern Christianity and Politics in Twenty-first Century: an Overview. In: Lucian Leustean (ed.) Eastern Christianity and Politics in Twentyfirst Century. London: Routledge.

Nikolova, Silvia 2006. Culvuja 2006. Katolicite veche sas svoja katedrala v Sofija [The Catholics are already with Their Cathedral in Sofia]. Duma, 22.05. Available at https://web.archive.org/web/20070927041157/http://www.duma. bg/2006/0506/220506/obshtestvo/ob-4.html, last accessed on 20.05.2018.

Pelovska, Maia 2006. Nova katolicheska katedrala v Sofija [New Catholic Cathedral in Sofia]. Paduo Balgarija, 22.05. Available at https://web.archive.org/ web/20070930185542/http://www.bnr.bg/RadioBulgaria/Emission_Bulgarian/ Theme_IstoriaIReligia/Material/katedrala_Sv_Yosif.htm, last accessed on 20.09.2017.

Petrov, Petăr 2000. Between Christianity and Socialism: Syncretistic Tendencies in Ritual Culture. Ethnologia Balkanica, Vol. 4, pp. 132-146.

Serafimova, Maria 2011. Religion is a Support for Social Solidarity. Statistics. National Statistical Institute, Republic of Bulgaria, No. 3-4, pp. 114-124.

2011 Population Census - main Results. National Statistical Institute, Republic of Bulgaria. http://www.nsi.bg/census2011/PDOCS2/Census2011final_en.pdf, last accessed on 20.05.2018. 
Rasa Račiūnaitè-Paužuolienè

Population by districts, municipalities, place of residence and sex. National Statistical Institute, Republic of Bulgaria. 31.12.2017. http://www.nsi.bg/en/content/6704/ population-districts-municipalities-place-residence-and-sex, last accessed on 20.05.2018.

I-IV. The material of field research, written by the author in Sofia, Plovdiv and it's region in 2010 and 2017. 